\title{
EMPIRICAL COEFFICIENTS FOR ESTIMATING EVAPOTRANSPIRATION OF SCOTS PINE (PINUS SYLVESTRIS) - PRELIMINARY RESEARCH
}

\author{
Malgorzata Biniak-Pierog, Andrzej Zyromski, Kryspin Swider, Romuald Zmuda \\ Wroclaw University of Environmntal and Life Sciences, Poland \\ malgorzata.biniak-pierog@upwr.edu.pl, andrzej.zyromski@upwr.edu.pl, \\ kryspin.swider@upwr.edu.pl, romuald.zmuda@upwr.edu.pl
}

\begin{abstract}
The objective of this study was to develop empirical coefficients for the estimation of evapotranspiration of Scots pine (Pinus sylvestris). A field experiment was conducted in the area of the Department Agro- and Hydrometeorology Observatory, University of Environmental and Life Sciences in Wrocław, Poland, from the $1^{\text {st }}$ of May till the $31^{\text {st }}$ of October, 2016. Measurements of evapotraspiration (ETR) were conducted in soil evaporimeters in three replicates. In parallel to the evaporimeter measurements, direct measurements of actual values of evaporation from open water surface (EW) were conducted with the use of an evaporimeter type EWP 992. In addition, the diurnal values of index evaporation were calculated with the FAO Penman-Monteith formula (EP). Empirical decade indices for the estimation of Scots pine evapotranspiration were determined in two variants. The first variant consisted in the determination of the quotient of measured evapotranspiration ETR and evaporation from open water surface $E W$ (index $k w$ ). In the second variant, the components of the quotient were the ETR and the index evaporation calculated with the FAO Penman-Monteith formula $(E P)$ (index $\mathrm{kp}$ ). The conducted analysis showed that variation in the values of evapotranspiration totals is more pronounced with extension of the time step, for which it is summed up. Basing on precipitation water alone, Scots pine adapts its evapotranspiration to the rhythm of water supply. In the case of the conditions of Wrocław, the maximum evapotranspiration total for a month occurs in July. Analyses of the possibility of determination of empirical indices on the basis of measurements of evaporation from open water surface performed by means of the evaporimeter type EWP 992 and of diurnal values of index evaporation calculated with the FAO-Penman-Monteith formula indicate a possibility of spatial interpretation of Scots pine evapotranspiration.
\end{abstract}

Keywords: evapotranspiration, soil evaporimeters, empirical coefficient, Scots pine (Pinus sylvestris).

\section{Introduction}

Evapotranspiration is one of the principal components of water balance, on which most climatic models are based. In the case of trees, knowledge of the process in the aspect of climate change is highly important. In the process of photosynthesis, trees absorb carbon dioxide and produce oxygen [1]. As reported by the Canadian Environmental Assessment Agency, one tree of $10 \mathrm{~m}$ height produces an average of about 118 kilograms of oxygen per year, while a human uses about $180 \mathrm{~kg}$ of that gas. Through the process of evapotranspiration, trees contribute, among other things, to a reduction of air temperature in their vicinity, and grown in suitable plantings they can significantly reduce the occurrence of the effect of "urban heat island" in urban environments, and improve the microclimate of those sites.

Over the years a number of methods have been developed for the determination of the amount of evapotranspiration, as well as of its individual components. These include, e.g. direct measurements by means of lysimeters $[2 ; 3]$, the method of soil water balance $[4 ; 5]$, measurements of water flow in tree trunks $[6 ; 7]$, eddy covariance $[8 ; 9]$, or water balance of catchment basin $[8 ; 10 ; 11]$. The methods differ in the space and time scale, number of measured components of the process of evapotranspiration, assumptions, technical difficulty, or values of measurement error.

The study of the evapotranspiration of trees is a complex process. For its elucidation it is necessary to create conditions that will reflect the environment of their growth. For this purpose one should isolate individual trees so that their root systems are situated in soil monoliths, separated from the possibility of water replenishment in the soil through capillary rise. Another equally important element is to set up a field experiment in such a way as to avoid the oasis effect, i.e. to create such conditions for the growth of trees that they can grow in a dense enclave, as it is in natural conditions. Such conditions can be achieved only in lysimeters or in soil evaporimeters with adequate surface area and thickness of soil monoliths. Methods for the study of the process of evapotranspiration of crop plants with annual cycle are largely researched. In the past as well as currently precise experimental methods have been and are in use, in the form of abovementioned lysimeters or soil evaporimeters with the possibility of soil texture modelling, as in the case of lysimeters [12-16]. Whereas, the study 
of evapotranspiration of trees is a complicated process due to the size of the plants and to their multiyear growth conditions. These limitations cause that only few research centres conduct field experiments of this kind.

In the literature one can often encounter various kinds of empirical indices allowing to estimate the value of evapotranspiration on the basis of analysis of evaporation from open water surface or of the index evaporation calculated according to the FAO Penman-Monteith method, treated as a reference method $[6 ; 13 ; 17 ; 18]$. A combination of those two methods yields satisfactory results.

The objective of this study was to develop empirical coefficients for the estimation of evapotranspiration of Scots pine (Pinus sylvestris). It is common opinion that coniferous forests have a significant effect on the environment and contribute to, e.g., an enhancement of water retention of areas in which they grow, modify the microclimate in manner friendly to man, and intercept considerable amounts of pollutants from the air. For these reasons, it is Scots pine that should be used for afforestation of poor soils.

\section{Materials and methods}

A field experiment was conducted in the area of the Department Agro- and Hydrometeorology Observatory, Faculty of Environmental Engineering and Geodesy, University of Environmental and Life Sciences in Wrocław, Poland, from the $1^{\text {st }}$ of May till the $31^{\text {st }}$ of October, 2016 (summer halfyear). The experiment covered the fifth year of cultivation of Scots pine (Pinus sylvestris) on a postarable soil. Measurements of evapotraspiration $(E T R)$ were conducted in soil evaporimeters with area of $0.3 \mathrm{~m}^{2}$ and $0.7 \mathrm{~m}$ soil monolith thickness, at 24-hour time step, in three replicates (ETR $1 \div$ ETR 3). To avoid the oasis effect, the soil evaporimeters were installed so that the trees covered by the measurements grew in a compact enclave, like in natural conditions (Fig. 1). The operating principle of a soil evaporimeter consists in periodic measurements of changes of soil mass in the pot, caused by water evaporation and migration to deeper soil layers. In the case of precipitation, very accurate estimation of its amount is necessary. For the determination of plant evaporation, the dimensions of evaporimeters should ensure adequate soil mass in the pot, meeting the requirements of the root layer. For this reason, the evaporimeters used in the field experiment have soil monoliths with thickness of $0.7 \mathrm{~m}$, placed in steel pots with larger diameters to allow their isolation from the effect of groundwater. The instruments used allow measurements with accuracy of $0.1 \mathrm{~mm}$ and 24-hour time step. Their operation consists solely in readouts of the position in indicators on the scales of mass and infiltration volume.

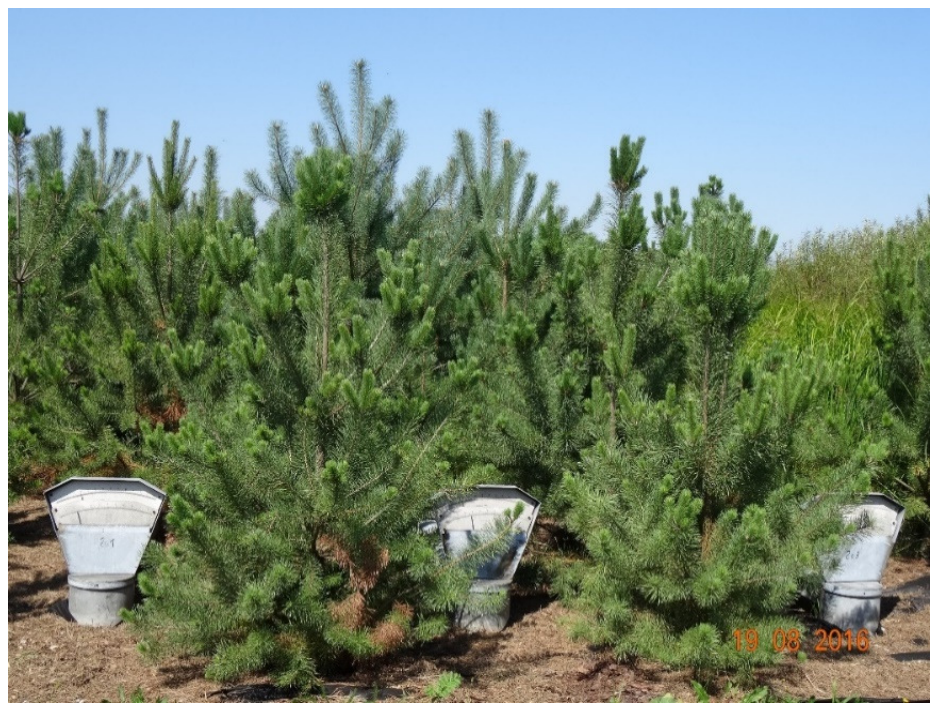

Fig. 1. Soil evaporometers installed in compact enclave of Scots pine in field experiment

In parallel to the evaporimeter measurements, direct measurements of actual values of evaporation from open water surface $(E W)$ were conducted with the use of the evaporimeter type EWP 992, placed beneath a louvered roofing. In addition, the diurnal values of index evaporation were calculated with 
the FAO Penman-Monteith formula $(E P)$, using the original software EVAPO that is described in detail in the publication by Chieng [19].

In the first stage of analyses, on the basis of the measured diurnal values of pine evapotranspiration in each of the evaporimeters, the actual values were calculated taking into account corrections for water influx in the form of diurnal precipitation totals, and outflow in the form of infiltration.

In the second stage, empirical decade indices for the estimation of Scots pine evapotranspiration were determined in two variants. The first variant consisted in the determination of the quotient of measured evapotranspiration ETR and evaporation from open water surface $E W$ (index $k w$ ). In the second variant, the components of the quotient were the ETR and the index evaporation calculated with the FAO Penman-Monteith formula $(E P)$ (index $k p$ ). For the determination of the empirical indices the decade time interval was adopted to ensure stability of the values obtained. The choice of the decade intervals resulted from the fact that diurnal values of the determined indices were highly varied, and their values resulted from the high diurnal variation of meteorological factors that determine the process of evaaporation. To evaluate the variation of the empirical indices $\mathrm{kw}$ and $\mathrm{kp}$, the same relationships were also determined for monthly intervals. The analyses conducted in the study are of a pilot character, due to the short period of the research.

To acquire knowledge on the weather conditions in the course of the experiment, measurements of the basic meteorological elements were conducted. Their estimation was made on the basis of mean decade values of air temperature and precipitation totals in those periods. The adopted reference background was the 30-year period of 1981-2010, currently recommended as climatological norm. Characterisation of the thermal-precipitation conditions was performed using the standard proposed by Biniak-Pieróg [20]. On that basis it was concluded that the summer half-year of 2016 was warm. Warm and very warm decades were dominant, observed primarily in the period from the $3^{\text {rd }}$ decade of May till the $3^{\text {rd }}$ decade of September, included. With regard to atmospheric precipitation, the analysed half-year period corresponded to the norm, with a total of $P 340.2 \mathrm{~mm}$. Analysis of subsequent decades revealed domination of dry (6) and medium dry (3) decades, interspaced with normal periods (6) and sporadically with medium wet and wet ones (a total of 4). Figure 2 presents the runs of decade values of air temperature and atmospheric precipitation during the period of the study.

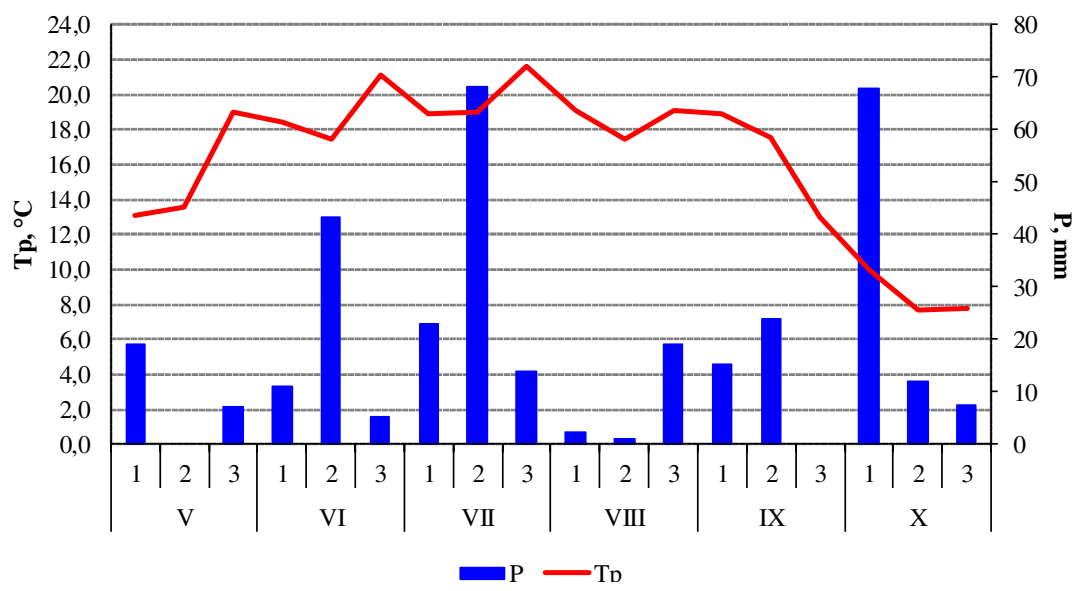

Fig. 2. Decade variation of mean values of air temperature and precipitation totals from May 1 till October 31, 2016

\section{Results and discussion}

Figure 3 presents the variation of diurnal values of Scots pine evapotranspiration averaged for three replicates, against the background of diurnal atmospheric precipitation totals from May till October, 2016. The obtained decreasing trend of ETR $1 \div 3$ is clearly visible in the course of the vegetation period. However, from the statistical point of view it is insignificant, which is indicated by the low value of the coefficient of determination $\left(R^{2}=0,0451\right)$.

Variation of the values of evapotranspiration totals is more observable with extension of the time step for which it is summed up. This is presented in Figures 4 and 5. 


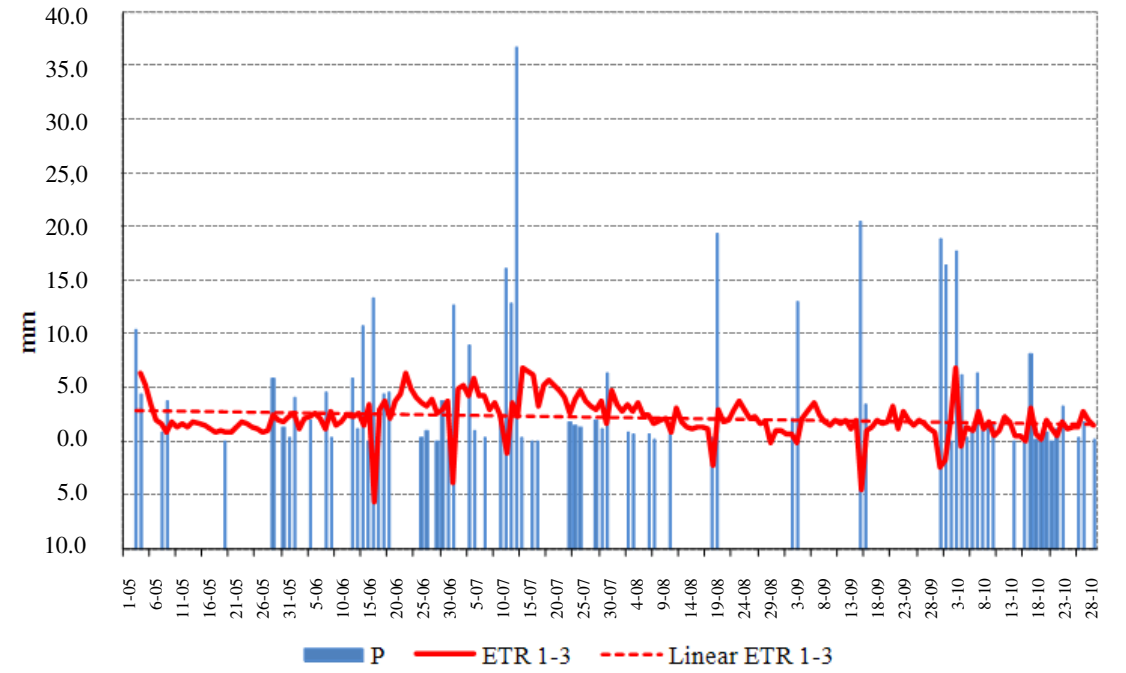

Fig. 3. Diurnal variation of mean values of Scots pine evapotranspiration $($ ETR $1 \div 3)$ versus run of diurnal precipitation totals $(P)$ from May 1 till October 31, 2016

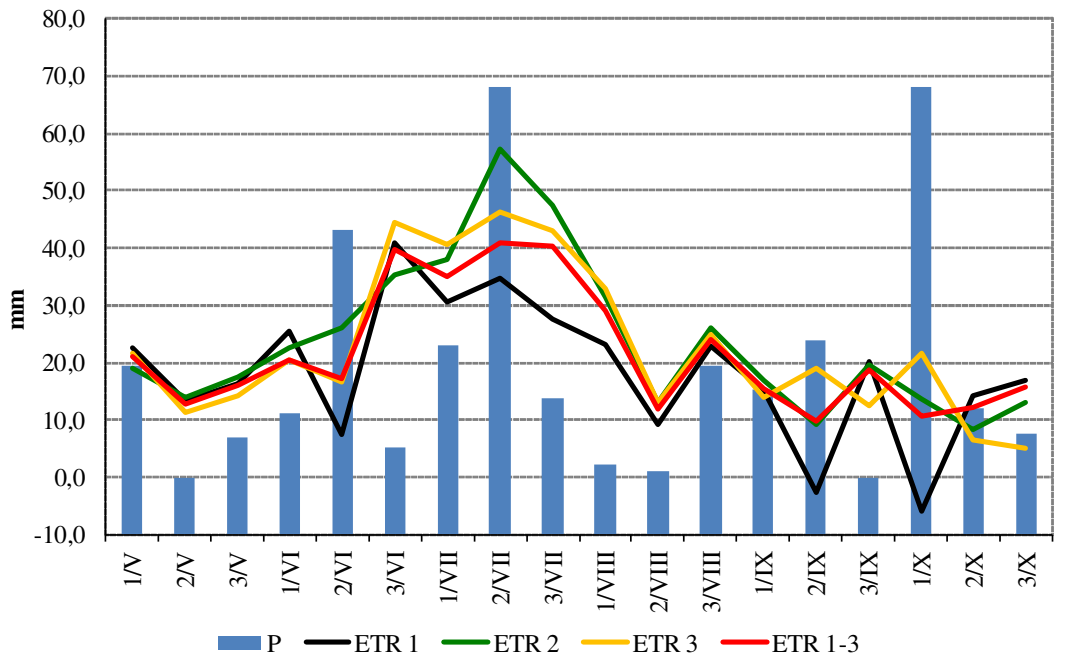

Fig. 4. Decade values of Scots pine evapotranspiration measured in evaporimeters 1-3 (ETR $1 \div$ $E T R$ 3) and mean values $(E T R \quad 1 \div 3)$ versus diurnal precipitation totals $(P)$

from May 1 till October 31, 2016

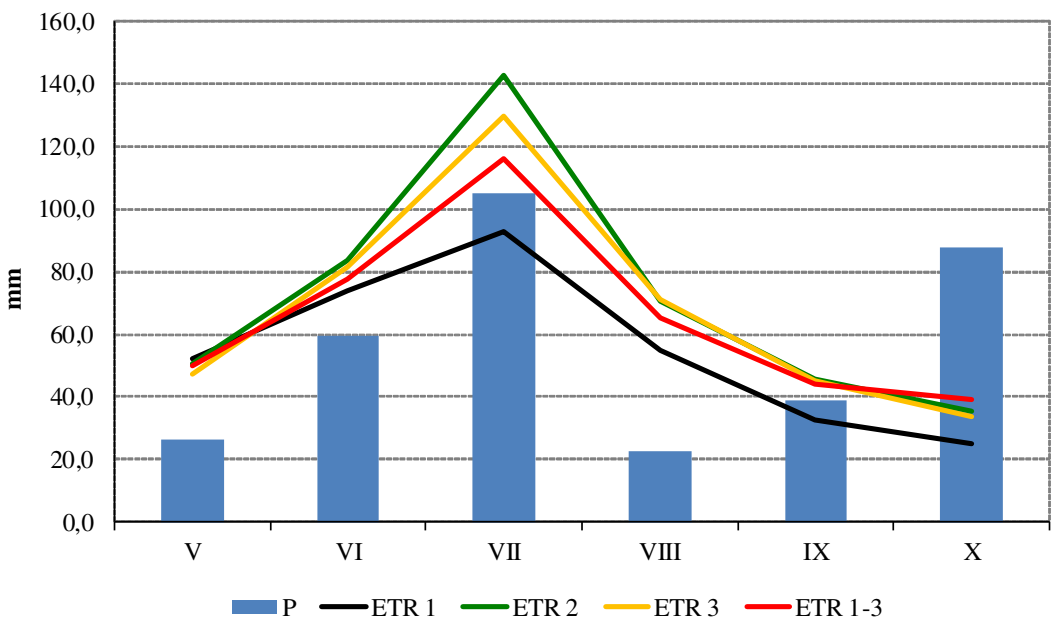

Fig. 5. Monthly values of Scots pine evapotranspiration measured in evaporimeters 1-3 (ETR $1 \div$ $E T R 3)$ and mean values $(E T R 1 \div 3)$ versus diurnal precipitation totals $(P)$

from May 1 till October 31, 2016 
Basing on precipitation water alone, Scots pine adapts its evapotranspiration to the water supply rhythm. In the case of the Wrocław conditions, the maximum evapotranspiration total occurred in July $(116.3 \mathrm{~mm})$, and the lowest in October $(38.9 \mathrm{~mm})$.

In the course of the field experiment it was observed that in the conditions of no access of the root system of Scots pine to ground waters, i.e. in conditions created by the soil evaporimeters, the process of evpotranspiration is significantly limited. This is reflected also in limited growth capacity of the trees. In addition, both the amount of retained water and the value of evapotranspiration of individual trees depend on their location in the forest enclave.

In the second stage, basing on the averaged decade values of actual evapotranspiration ETR $1 \div 3$ of Scots pine and the measured decade values of evaporation from open water surface $E W$ and decade values of potential evaporation calculated with the FAO-Penman-Monteith formula, the empirical indices $k w$ (variant I) and $k p$ (variant II) for the estimation of evapotranspiration of the trees were determined. Their variation is presented in Figure 6.

The decade values of index $k w$, obtained on the basis of measured values of evaporation from open water surface $E W$, varied from 0.249 for the $3^{\text {rd }}$ decade of May to 1.629 for the $3^{\text {rd }}$ decade of October. In the second variant, in which the values of potential evaporation calculated with the FAO Penman-Monteith formula were used, the range of variation of index $k p$ assumed values from 0.340 for the $2^{\text {nd }}$ decade of August and comparable 0.341 for the $3^{\text {rd }}$ decade of May, to 2.135 for the $3^{\text {rd }}$ decade of October. As can be seen from the Figure, in a large majority of decades in both variants similar values of indices $k w$ and $k p$ were obtained. This relates in particular to the periods from the $1^{\text {st }}$ decade of May to the $2^{\text {nd }}$ decade of June, inclusive, and from the $2^{\text {nd }}$ decade of August to the $3^{\text {rd }}$ decade of October, also inclusive. Distinctly higher values of the empirical index $k p$, determined on the basis of values of potential evaporation calculated with the FAO method, were obtained in the period from the $2^{\text {nd }}$ decade of July to the $1^{\text {st }}$ decade of August.

As follows from the analysis of weather conditions, in terms of moisture the $2^{\text {nd }}$ decade of July was classified as wet (precipitation total of $68 \mathrm{~mm}$ ), and in terms of thermal conditions as warm. That allowed water to accumulate in the substrate, which was reflected in higher ETR values in that and the following decade. A comparably high difference in the values of indices $k p$ and $k w$ was obtained for the $3^{\text {rd }}$ decade of October.

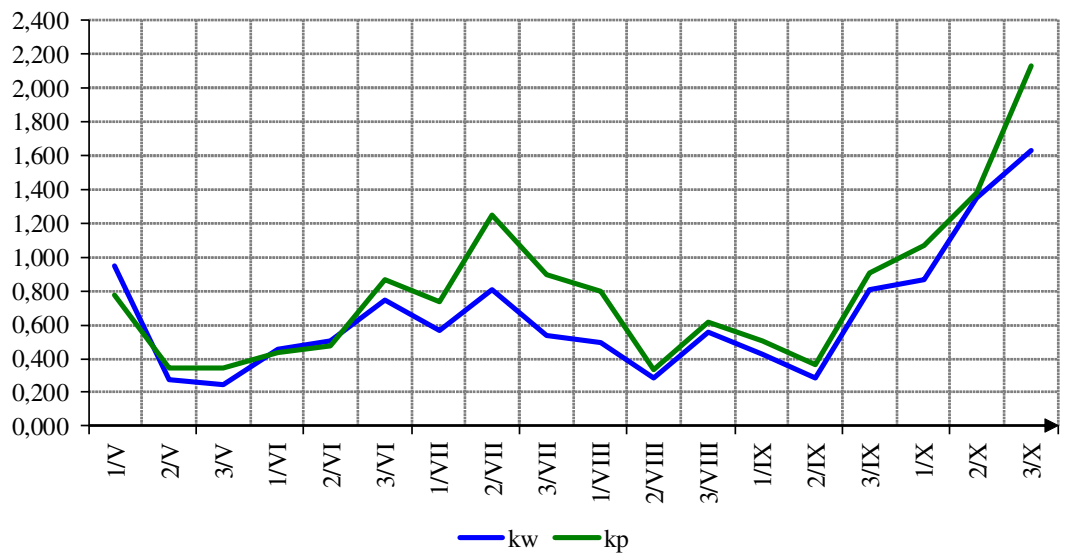

\section{Fig. 6. Variation of decade values of indices $k w$ and $k p$ for estimation of Scots pine evapotranspiration}

The calculated values of the empirical index $k w$ for the monthly intervals varied from 0.373 in May to 1.244 in October. Whereas, the empirically obtained values of the index $k p$, determined on the basis of the values of potential evaporation calculated with the FAO method, were higher every time and assumed values in the range from 0.448 in May to 2.135 in October, the highest values being observed, as in the case of the decade values, in July (Fig. 7). However, the extension of the time interval caused a distinct attenuation of variation in the obtained values of the indices $k w$ as well as $k p$. 


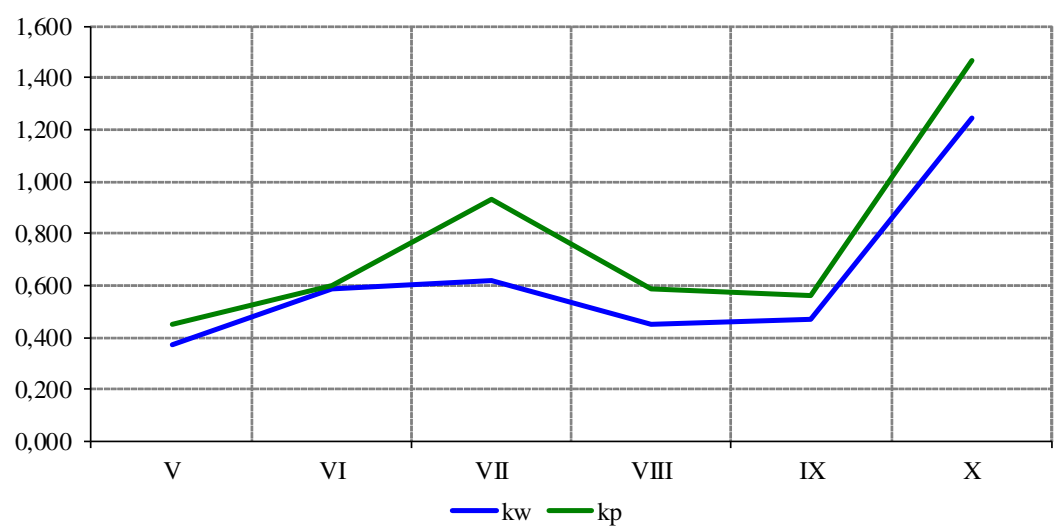

Fig. 7. Variation of monthly values of indices $k w$ and $k p$ for estimation of Scots pine evapotranspiration

\section{Conclusions}

1. The trend obtained on the basis of diurnal values of Scots pine evapotransporation is a decreasing one, and it is observable for the entire period of vegetation, but from the statistical point of view it is insignificant, which is indicated by a low value of the coefficient of determination.

2. Variation in the values of evapotranspiration totals is more pronounced with extension of the time step, for which is it summed up.

3. Basing on precipitation water alone, Scots pine adapts its evapotranspiration to the rhythm of water supply. In the case of the conditions of Wrocław, the maximum evapotranspiration total for a month occurs in July.

4. Analyses of the possibility of determination of empirical indices on the basis of measurements of evaporation from open water surface performed by means of the evaporimeter type EWP 992 and of diurnal values of index evaporation calculated with the FAO-Penman-Monteith formula indicate a possibility of spatial interpretation of Scots pine evapotranspiration.

5. The determined runs of variation of the empirical indices, in spite of the fact that the analysis was performed for results from a single year, indicate similarity of their values, when comparing the two methods.

\section{References}

[1] Kazak J., Malczyk J., Castro D. G. etc. Carbon sequestration in forest valuation. Real Estate Management and Valuation, vol. 24, 2016, pp. 76-86.

[2] Stein J., Caissy R., Plamondon A. P. etc. Estimation of potential evapotranspiration with shallow lysimeters in a forest tree nursery. The Forestry Chronicle, vol. 71, 1995, pp. 755-758.

[3] Johnson R.S., Williams L.E., Ayars J.E., Trout T.J. Weighing lysimeters aid study of water relations in tree and wine crops. California Agriculture, vol. 59, 2005, pp. 133-136.

[4] Wang S., Fu B. J., Gao G. Y. etc. Soil moisture and evapotranspiration of different land cover types in the Loess Plateau, China. Hydrology and Earth System Sciences, vol. 16, 2012, pp. 28832892.

[5] de Souza J. L. M., Freitas Fezer K., Gurski B. C. etc. Soil water balance in different densities of Pinus taeda in Southern Brazil. Acta Scientiarum. Agronomy, vol. 38, 2016, pp. 265-271.

[6] Boczoń A., Brandyk A., Wróbel M. etc. Transpiracja drzewostanu i ewapotranspiracja ekosystemu sosnowego $\mathrm{w}$ powiązaniu $\mathrm{z}$ ewapotranspiracją potencjalną wyznaczoną różnymi metodami (Transpiration of a stand and evapotranspiration of Scots pine ecosystem in relation to the potential evapotranspiration estimated with different methods). Sylwan, vol. 159, 2015, pp. 666-674. (In Polish)

[7] Wang H., Trtzlaff D., Dick J.J. etc. Assessing the environmental controls on Scots pine transpiration and the implications for water partitioning in a boreal headwater catchment. Agricultural and Forest Meteorology, 2017, pp. 58-66. 
[8] Wilson K.B., Hanson P.J., Mulholland P. J. etc. A comparison of methods for determining forest evapotranspiration and its components: sap-flow, soil water budget, eddy covariance and catchment water balance. Agricultural and Forest Meteorology, vol. 106, 2001, pp. 153-168.

[9] Barbour M. M., Hunt J.E., Walcroft A.S. etc. Components of ecosystem evaporation in a temperate coniferous rainforest, with canopy transpiration scaled using sapwood density. New Phytologist, vol.165, 2005, pp. 549-558.

[10] Gielen B., Verbeeck H., Neirynck J. etc. Decadal water balance of temperate Scots pine forest (Pinus sylvestris L.) based on measurements and modeling. Biogeosciences, vol. 7, 2010, pp. 1247-1261.

[11] Skubel R., Arain M.A., Peichl M., etc. Age effect on the water-use efficiency and water-use dynamics of temperate pine plantation forests. Hydrological Processes, vol. 29, 2015, pp. 41004113.

[12] Bryla D.R., Trout T. J., Ayars J. E. Weighing Lysimeters for developing crop coefficients and efficient irrigation practices for vegetable crops. HortScience, vol. 45, 2010, pp. 1597-1604.

[13] Fisher D.K. Simple weighing lysimeters for measuring evapotranspiration and developing crop coefficients. International Journal of Agricultural and Biological Engineering, vol. 5, 2012, pp. $35-43$.

[14]Żyromski A. Szulczewski W., Biniak-Pieróg M., Okrasińska H. Prosty model ewapotranspiracji dla wybranych roślin energetycznych (Simple model of evapotranspiration of selected energy plants). Water-Environment-Rural Areas: Woda - Środowisko - Obszary Wiejskie, vol. 12/2 (38), 2012, pp. 391-399. (In Polish)

[15] Szajda J., Łabędzki L. Wyznaczanie ewapotranspiracji rzeczywistej użytków zielonych na podstawie ewapotranspiracji maksymalnej i potencjału wody w glebie (Determination of actual evapotranspiration of grassland on the basis of maximum evapotranspiration and soil water potential). Water-Environment-Rural Areas: Woda-Środowisko-Obszary Wiejskie, vol. 16/1 (53), 2016, pp. 71-92. (In Polish)

[16] Czyżyk F., Steinhoff-Wrześniewska A. Zróżnicowanie ewapotranspiracji niektórych gatunków roślin uprawnych $\mathrm{w}$ warunkach różnego nawożenia (Variety of evapotranspiration of certain cultivated plants in conditions of different fertilization). Water-Environment-Rural Areas: WodaŚrodowisko-Obszary Wiejskie, vol. 17/4 (60), 2017, pp. 25-36. (In Polish)

[17] Pandey P.K., Pandey V. Lysimeter based crop coefficients for estimations of crop evapotranspiration of Black gram (Vigna Mungo L.) in sub-humid region. International Journal of Agricultural and Biological Engineering, vol. 4, 2011. pp. 50-58.

[18]Żyromski A., Biniak-Pieróg M., Szulczewski W., Kordas L., Kabała C., Gałka B. Mathematical modelling of evapotranspiration of selected energy crops. Monograph: Monografia. Wroclaw University of Environmental and Life Sciences, 2016, pp. 158.

[19]Chieng S., Biniak-Pieróg M., Kamińska J., Szulczewski W., Żyromski A. Aplikacja Evapo narzędzie do wyznaczania ewapotranspiracji metodą FAO - Penman Monteith (EVAPO application - a tool for determining evapotranspiration by FAO - Penman - Monteith method). Infrastructure and Ecology of Rural Areas: Infrastruktura i Ekologia Terenów Wiejskich, vol. 3/III, 2012, pp. 55-66. (In Polish)

[20] Biniak-Pieróg M. Monitoring opadu atmosferycznego i wilgotności gleby jako podstawa oceny efektywnego zasilania profilu glebowego w wodę (Monitoring of atmospheric precipitation and soil moisture as basis for the estimation of effective supply of soil profile with water). Monograph: Monografia. Wroclaw University of Environmental and Life Sciences, 2017, pp. 198. (In Polish) 